\title{
Electromagnetic-acoustic transducers for ultrasonic measurements, testing and diagnostics of ferromagnetic metal products
}

\author{
Salam Bussi, G. Suchkov, R. Mygushchenko, O. Kropachek, \\ S. Plesnetsov \\ National Technical University "Kharkiv Polytechnic Institute", Kyrpychova Str., 2, 61002, Kharkiv, Ukraine \\ hpi.suchkov@gmail.com
}

Abstract

An effective type of ultrasonic method is the electromagnetic-acoustic method, especially in determining the quality of ferromagnetic products. The main factor determining the efficiency of using electromagnetic-acoustic transducers is the magnitude of the induction of a polarizing magnetic field, which is determined by the source.

The studies carried out in the framework of this activity were aimed at solving the problems of high-quality measuring testing of metal products from ferromagnetic materials by electromagnetic-acoustic transducers.

The requirements are formulated for a pulsed source of a polarizing magnetic field, inductors, and core as part of electromagnetic-acoustic transducers. Taking into account the requirements, structural solutions have been proposed for constructing electromagnetic-acoustic transducers with a flat two-window inductor and a flat high-frequency inductor.

Experimental studies aimed at improving ultrasonic electromagnetic-acoustic transducers with pulsed magnetic field sources have been performed. The possibility of providing the sensitivity of new transducers with thickness measurement, measuring control and diagnostics is shown. Technical solutions are proposed that reduce the effect on ultrasonic pulses of the received Barkhausen noise and coherent interference from the magnetostrictive conversion of electromagnetic energy into ultrasonic.

The efficiency of using electromagnetic-acoustic transducers with a pulsed polarizing magnetic field is shown for measuring quality control of ferromagnetic products made by rolling, stamping and the like.

Keywords: ultrasonic waves; electromagnetic-acoustic transducer; impulse magnetization; research material; ferromagnetic; inductance coil; measurement; testing; diagnostics; thickness measurement.

\section{Introduction}

Ultrasonic methods are widespread in measurements, control and diagnostic [1]. An effective type of ultrasonic method is the electromagnetic-acoustic (EMA) method, including in economic terms [2-3], especially when determining the quality of ferromagnetic rolled, stamped, forged products. The main factor that determines the efficiency of using EMA transducers (EMAT) is the induction magnitude of a polarizing magnetic field, which is formed by a suitable source. Often permanent magnets are used in EMAT, which leads to the strong attraction of the transducer to the ferromagnetic product, its wear, and in the case of portable devices to the difficulty of scanning the tested object (TO) by the operator, as well as to the sticking of the ferromagnetic scale, which is difficult to remove [1, 4-5].

Solving the above problems of the EMA method of measurement control is possible through using EMAT pulsed magnetic polarizing field sources [6-8]. However, when using pulsed magnetic polarizing field sources, there are a number of problems that do not significantly improve the conditions of measurement control: Barkhausen noise, coherent interference with the metallic elements of the transducer, etc. [6-8]. Therefore, studies aimed at solving the problems of quality measurement control of ferromagnetic materials of electromagnetic-acoustic transducers are relevant.

The aim of the work is to improve the EMAT for measuring control, thickness measurement and diagnostics, equipped with pulsed magnetic polarizing field sources.

The analysis of publications materials [1, 4, 8-9] made it possible to formulate the requirements for a pulsed polarizing magnetic field source in EMAT. The inductance coil (IC) of the pulsed polarizing magnetic field source should have a minimum inductance to ensure minimum pulse duration of the supply current (reducing power consumption). For this purpose, it is advisable to make such coils flat two-window from a whole plate of highly conductive and heat-conducting material. The core 


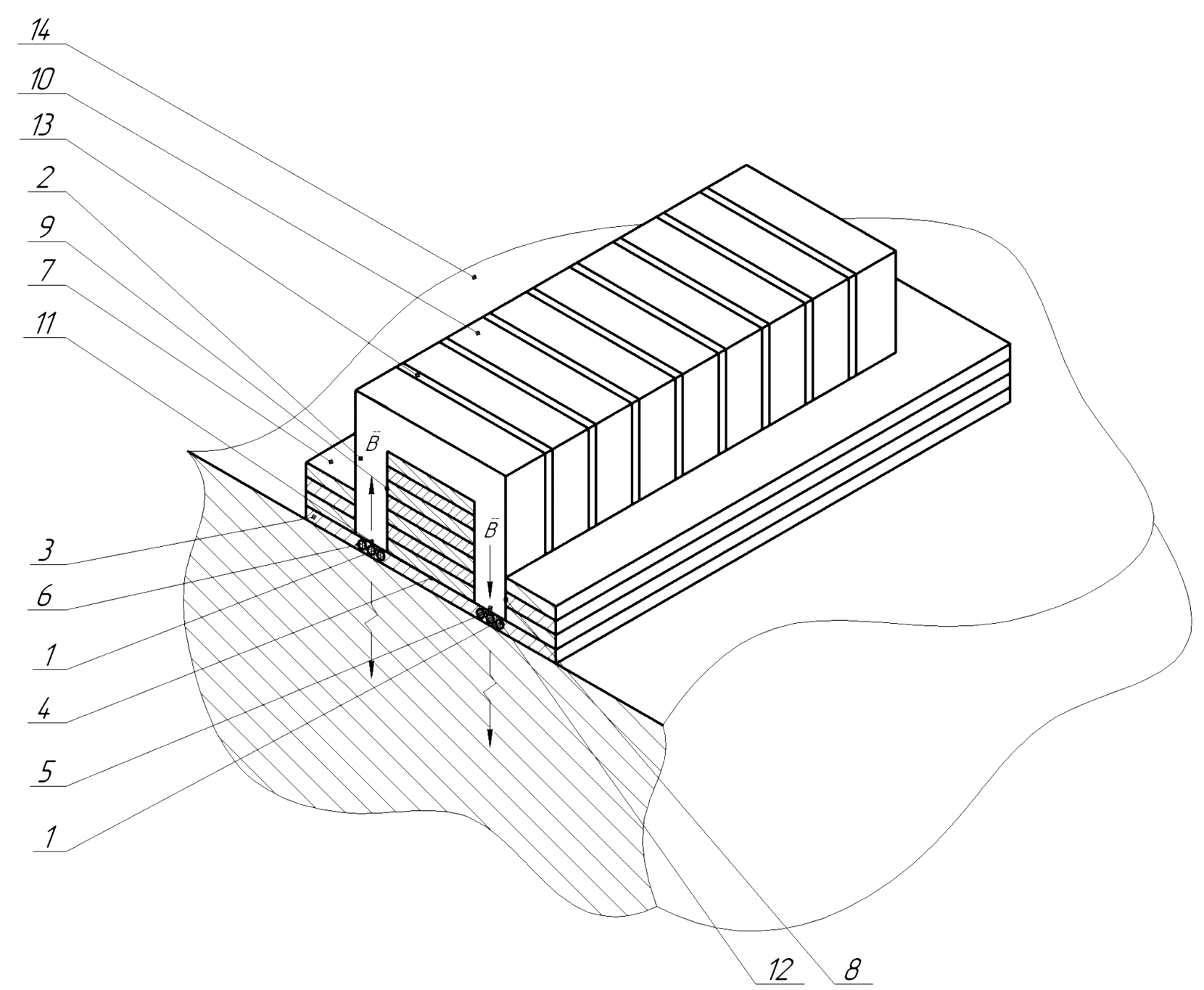

Fig. 1. Layout of a pulsed polarizing magnetic field source with a flat two-window inductance coil and a flat HFIC in EMAT

of the pulsed polarizing magnetic field source should not completely fill the openings of the IC to be U-shaped and inserted into the windows of the inductance coil. High-frequency induction coil (HFIC) of EMAT with their working parts is placed under the windows of the IC and the ends of the core, which provides excitation of in-phase ultrasonic pulses of considerable power. A simplified design of main elements of EMAT, which fulfills the requirements above defined, is shown in Fig. 1.

Fig. 1 shows: $1-$ flat high-frequency induction coils; $2-$ pulsed polarizing magnetic field source; $3-$ protecting surface; $4-$ a hole in the flat HFIC; 5 and 6 - linear work sections of parallel conductors of the flat HFIC; 7 - flat IC; 8 and 9 - rectangular holes in the flat IC; 10 - laminated U-shaped ferromagnetic core; 11 and 12 - end surfaces of ferromagnetic core; 13 - thick liquid; $14-$ TO. The arrows in the TO volume indicate the direction of spreading excited inphase linearly polarized shear ultrasonic pulses normal to the surface of the metal product $\boldsymbol{B}$ is the induction vector of a polarizing magnetic field, the directions of which are shown by arrows in the core.

EMAT works as follows. It is placed on the TO surface 14 , so that the protecting surface 3 is adjacent to the TO surface 14 . During the working process, in flat IC 7 a unipolar pulse of current $I$ in a shape close to rectangular is generated, Fig. 2a, with an effective time $T$. In rectangular holes 8 and 9 of the flat IC 7 , pulsed magnetic polarizing fields are excited, which induction vectors B are directed in opposite directions (shown by arrows) normally to the TO surface 14 .

Using a laminated U-shaped ferromagnetic core 10 , the induction $\mathrm{B}$ of the polarizing magnetic fields under the end surfaces 11 and 12 of the ferromagnetic core 10 and, accordingly, in the TO surface layer 14 is increased several times. Since the sensitivity of EMAT depends on the induction magnitude of the polarizing magnetic field as $B^{2}$, it also increases significantly.

Upon completing transient processes in the flat IC 7 from the start of the current pulse $I$, Fig. 2a shows batch high-frequency pulse $\mathrm{c}$ is excited in the flat HFIC1, Fig. $2 \mathrm{~b}$ shows its orientation in the linear working sections of the parallel conductors 5 and 6 of the flat HFIC 1. Accordingly, in the TO surface layer 14 under the linear working sections of the parallel conductors 5 and 6 of the flat HFIC 1 and under the end surfaces 11 and 12 of the ferromagnetic core 10 is formed by a high-frequency batch pulse of the electromagnetic field. 


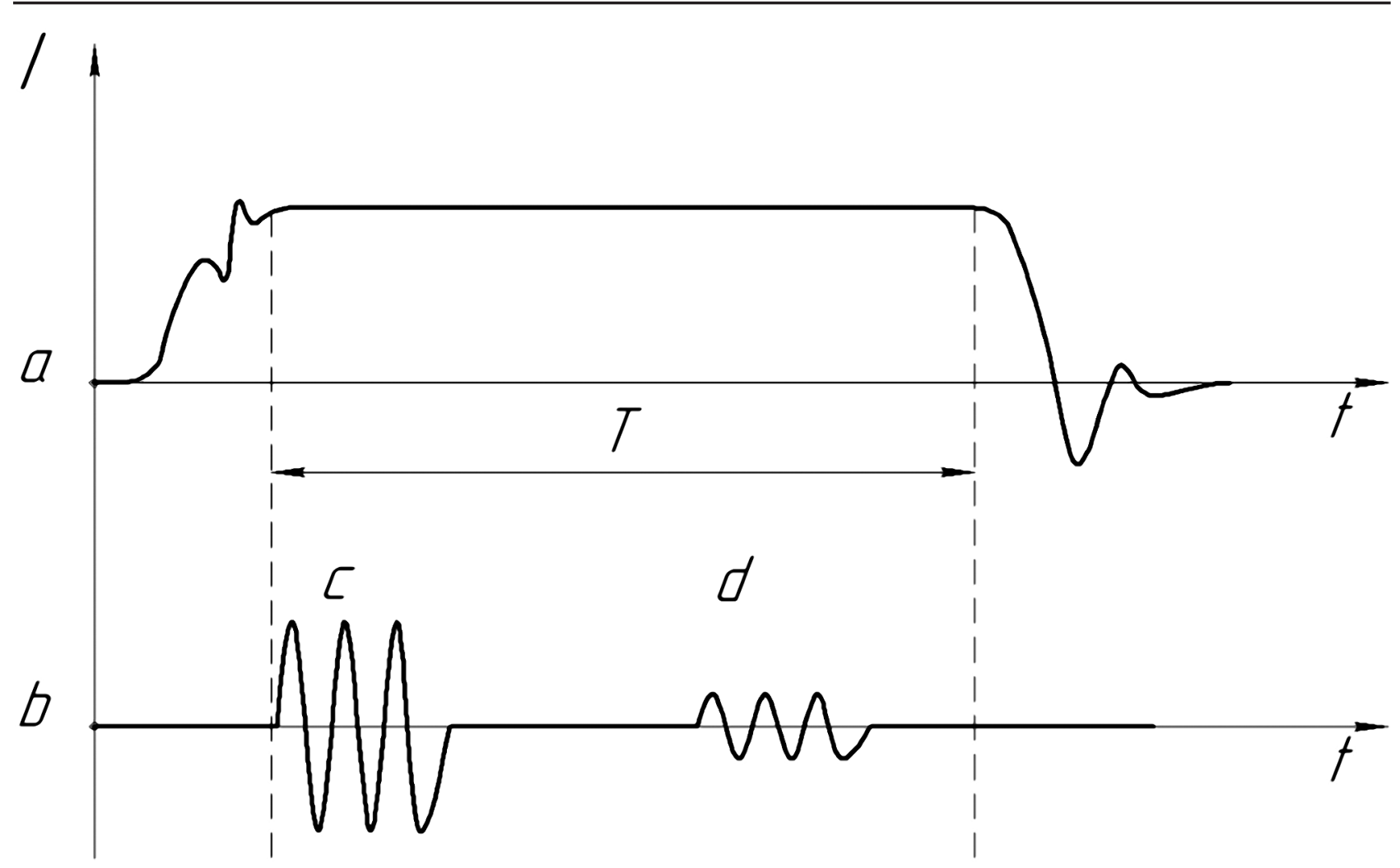

Fig. 2. Time-base sweeps for coil feed currents

The interaction of a polarizing magnetic field pulse and a high frequency electromagnetic field in the surface layer OC 14 causes the excitation of ultrasonic pulses with the same phase, which propagate in the volume TO 14 normally on its surface. The ultrasonic pulses reflected from TO 14 are received, for example, the impulse $d$ in Fig. $2 b$, due to the inverse EMA transformation, by linear working sections of parallel conductors 5 and 6 of the flat HFIC1 from the area of the pulsed polarizing magnetic field created by the pulsed polarizing magnetic field source 2 .

$\mathrm{U}$-shaped ferromagnetic core 10 is laminated, the choice of core material 10 with a low magnetostriction coefficient and the orientation of the core plates perpendicular to the conductors of linear working sections 5 and 6 of the flat high frequency coil of inductance 1 significantly reduces the amount of interference excited at the end surfaces 11 and 12 of the ferromagnetic core 10 due to magnetostrictive transformation. The interference at the end surfaces 11 and 12 of the ferromagnetic core 10 due to the Barkhausen effect is suppressed by filling the gaps between the plates of the mixed core 10 with a viscous fluid 13 , such as glycerol. The plates of the laminated core 10 should be electrically isolated from each other.

In addition, due to the short time $T$ of the current pulse $I$ in flat IC7, the pulling force of the EMAT to TO 14 is practically absent. As a result, damage to the EMAT is eliminated.

It is obvious that the effective operation of the developed EMAT design will be determined by the number of IC turns and its temperature regime, which is related to the significant impulse current supply power of the HFIC.

The study results on the influence of the number of IC turns on the ratio of the amplitudes of the information bottom signal and interference are shown in Table 1. The studies were performed on a sample of steel 45 and $40 \mathrm{~mm}$ thick without removing scale from its surface. The peak power value of the IC was $600 \mathrm{~A}$. The frequency of excited high-frequency ultrasonic pulses was $2.3 \mathrm{MHz}$. The time $T$ of the magnetization pulse was $200 \mu$ s. The dielectric layer between EMAT and TO was set equal to $0.2 \mathrm{~mm}$.

Analysis of the data in Table 1 shows that based on the number of turns of the flat inductance coil of the magnetic field source with a ferromagnetic core, it is advisable to choose equal to 3 . Further increase in the number of turns does not practically give additional growth.

Table 1

Influence of the number of turns of a flat IC HFIC EMAT with a laminated ferromagnetic core on the amplitude of the first bottom pulse

\begin{tabular}{|c|c|c|}
\hline No & $\begin{array}{c}\text { The number } \\
\text { of turns, pcs }\end{array}$ & $\begin{array}{c}\text { The amplitude ratio of the } \\
\text { first bottom pulse to the noise } \\
\text { amplitude, dB }\end{array}$ \\
\hline 1 & 1 & $24 \pm 2$ \\
\hline 2 & 2 & $32 \pm 2$ \\
\hline 3 & 3 & $38 \pm 2$ \\
\hline 4 & 4 & $40 \pm 2$ \\
\hline 5 & 5 & $41 \pm 2$ \\
\hline
\end{tabular}


The frequency influence of the TO sounding on the temperature IC HFIC with a mixed ferromagnetic core is studied. The results of the studies are shown in Table 2. The results indicated in Table 2 were obtained at an ambient temperature of $22{ }^{\circ} \mathrm{C}$. The current in the IC HFIC was $600 \mathrm{~A}$. The time $T$ of the magnetization pulse was $200 \mu \mathrm{s}$. The dielectric layer between the EMAT and the test sample of steel 45 with a thickness of $40 \mathrm{~mm}$ was set equal to $0.2 \mathrm{~mm}$.

Table 2

Influence of TO sounding frequency on temperature of flat two-window three-winding inductance coil of magnetic field source with ferromagnetic core

\begin{tabular}{|c|c|c|}
\hline No & Sounding frequency, $\mathrm{Hz}$ & Temperature, ${ }^{\circ} \mathrm{C}$ \\
\hline 1 & 10 & 22 \\
\hline 2 & 30 & 22 \\
\hline 3 & 50 & 29 \\
\hline 4 & 60 & 34 \\
\hline 5 & 70 & 44 \\
\hline 6 & 80 & 58 \\
\hline 7 & 100 & 86 \\
\hline
\end{tabular}

Analysis of Table 2 shows that for the sounding frequencies of TO up to $100 \mathrm{~Hz}$, when using heat-resistant insulation, EMAT cooling is not required. At $100 \mathrm{~Hz}$ sounding frequencies, it is possible to perform both section diagnostic of the TO volume as well as its sounding.

It should be noted that using EMAT model with a flat inductance coil of the magnetic field source with a ferromagnetic core allowed to preserve the duration of the probing impulse with interference (Fig. 3, position 1) in comparison with the EMAT design at work [8] and to significantly improve the ratio of the bottom pulse amplitude to the noise amplitude, Fig. 3 (positions 2, 3 and 4 are the first, second and third bottom pulses, respectively).

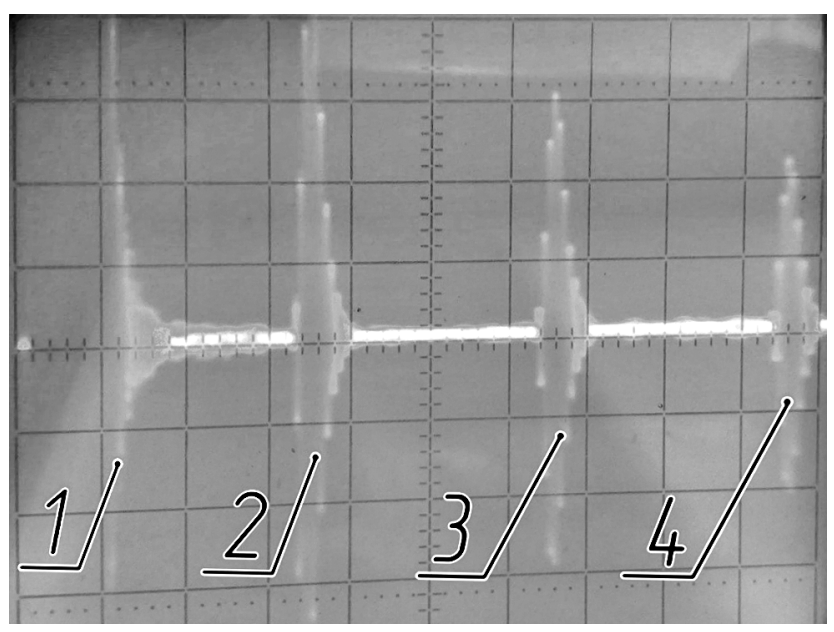

Fig. 3. Time-base sweep with bottom signals when using a flat three-turn inductance coil of EMAT magnetic field source with two windows and U-shaped laminated core

The data shown in Fig. 3 were obtained at a sounding frequency of $40 \mathrm{~Hz}$, ultrasonic oscillations frequency of $2.3 \mathrm{MHz}$, a peak high-frequency current in the HFIC $120 \mathrm{~A}$, pulse duration of the magnetization current $200 \mu \mathrm{s}$, magnetization current $600 \mathrm{~A}$. Measurements were taken from a sample of steel 45 through a mylar spacer $0.2 \mathrm{~mm}$ thick between the EMAT layout and the TO.

Analysis of the data shown in Fig. 3 in comparison with the data from [9] shows that with virtually the same duration of the sounding pulse with interference, the amplitude of the bottom pulses increased

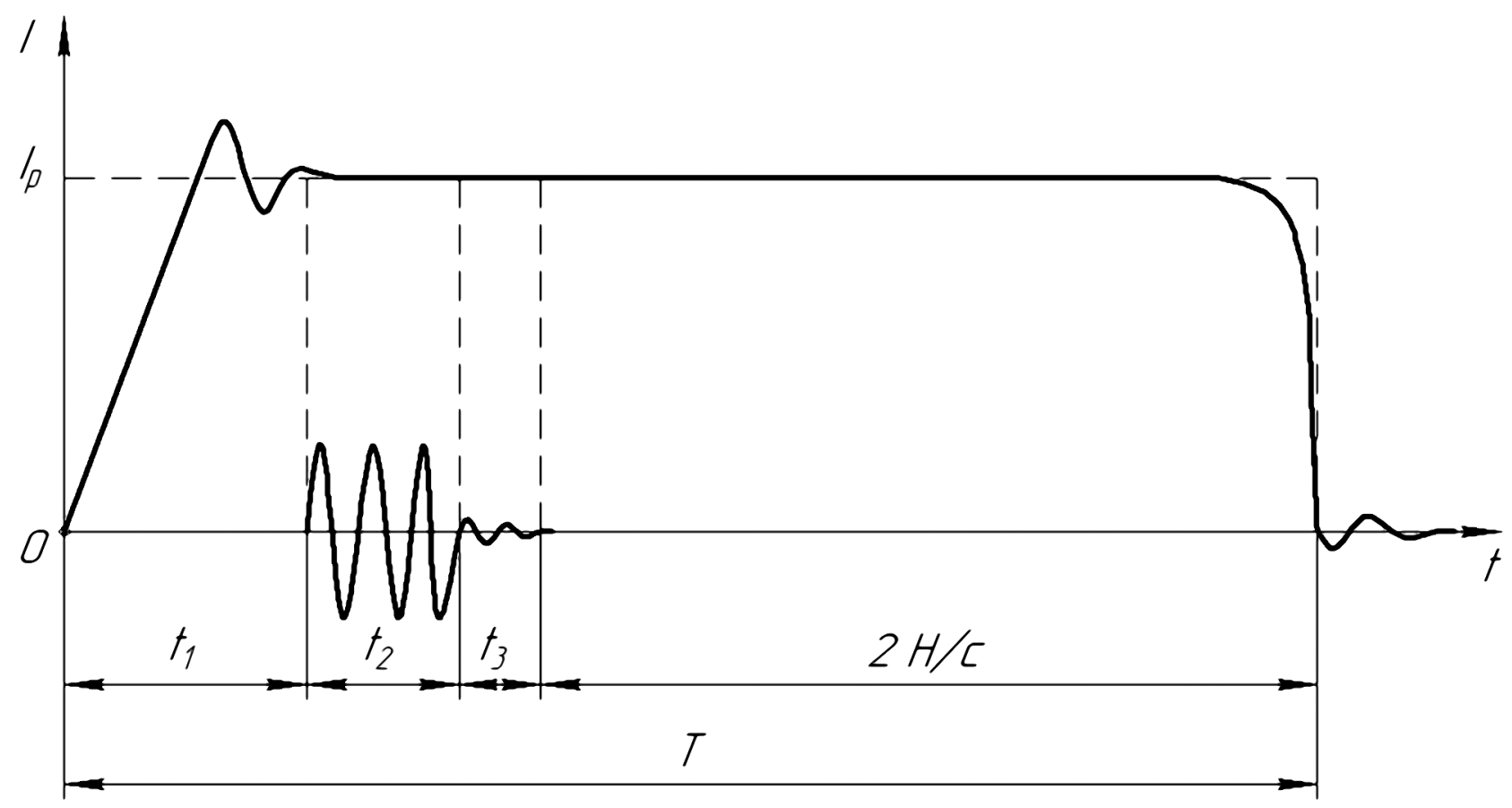

Fig. 4. To the explanation of timing for the EMAT receiving of ultrasonic pulses 


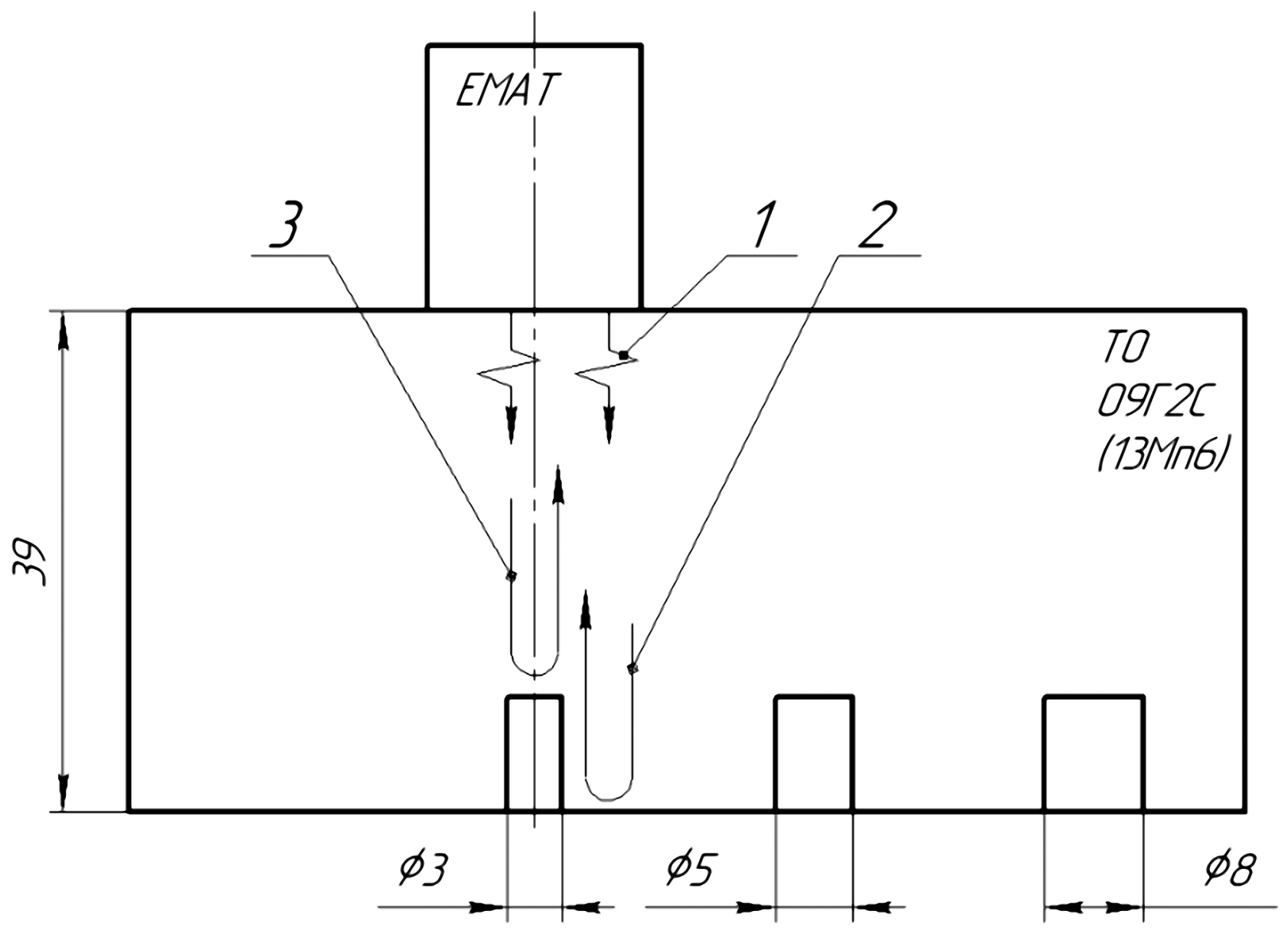

Fig. 5. Methodological scheme for detecting flat-bottomed reflectors in TO

more than 5 times. Such amplitude of useful pulses should be sufficient for the measurement control of ferromagnetic metal products.

The above research and development results allow us to formulate the list of operations of a new measurement control method that will ensure the effective operation of EMAT with pulsed magnetization:

- forming of two adjacent short-term magnetized sections with opposite direction of the magnetic induction vectors of the polarizing field in the surface layer of a ferromagnetic product;

- excitation in magnetized sections of batch high frequency pulses of electromagnetic field with oppositely directed vectors of intensity lasting for several periods of high frequency filling;

- excitation of the electromagnetic field pulses should be performed at a time equal to the time of transient processes to establish the operating value of induction of the polarizing magnetic field;

- receiving of ultrasonic pulses reflected from the product should be made in the period $t_{\mathrm{pr}}$, which is determined by the expression

$$
T-t_{1}-t_{2}-t_{3}<t_{\mathrm{pr}}=t_{1}+t_{2}+t_{3}+2 H / C,
$$

where $\mathrm{T}-$ magnetization pulse duration; $t_{1}-$ time of transient processes to establish induction working value of the polarizing magnetic field; $t_{2}-$ time of batch pulse of electromagnetic field; $t_{3}-$ time of damping current oscillations in a flat high frequency inductance coil; $H$ - product thickness or the distance in the product volume that are subject to ultrasonic measurement control, $\mathrm{mm} ; \mathrm{C}$ - velocity of spreading shear ultrasonic waves in the product material is subject to control, $\mathrm{mm} / \mu \mathrm{s}$.

The explanation of the magnitude $t_{\mathrm{pr}}$ choice is given in Fig. 4.

Checking the efficiency of measurement control by assessing the defects in the form of flat-bottomed wells was performed on the sample with models diameters of 3,5 and $8 \mathrm{~mm}$, Fig. 5 .

Measurement control was performed at a sounding frequency of $40 \mathrm{~Hz}$, ultrasonic oscillations frequency of 2.3 $\mathrm{MHz}$, a peak batch high-frequency current in the HFIC $120 \mathrm{~A}$, duration of batch current in 6 periods of the filling frequency, duration of magnetization pulse $200 \mu \mathrm{s}$, magnetization current was $600 \mathrm{~A}$. Measurements were taken through mylar spacer $0.2 \mathrm{~mm}$ between the EMAT layout and the sample. Methodological aspects of detecting defects are shown in Fig. 5.

Fig. 5 shows: 1 - excited ultrasonic pulses; $2-$ pulses reflected from the bottom surface; 3 - pulses reflected from the model of a $3 \mathrm{~mm}$ diameter flat-bottom defect. 
Fig. 6 shows a time-base sweep without information processing obtained during measurement control of the sample volume with a $3 \mathrm{~mm}$ flat-bottom drilling model according to Fig. 5 .

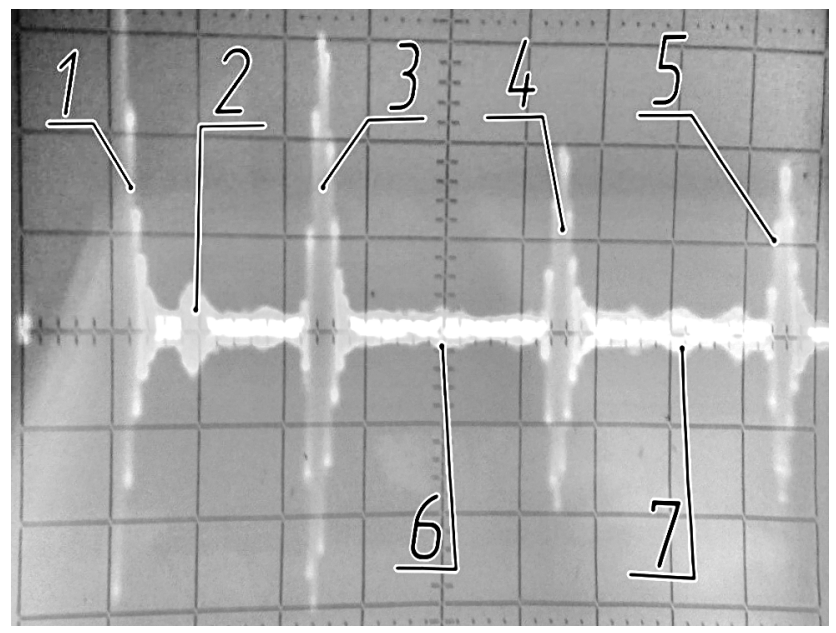

Fig. 6. Time-base sweep obtained from 09G2C steel with defect model in the form of a $3 \mathrm{~mm}$ flat-bottom reflector

Fig. 6 shows: 1 - sounding impulse with interference; 2 - lunar pulse reflected from the defect model; 3 - first bottom pulse; 4 - second bottom pulse; 5 - third bottom pulse; 6 and 7 - additional impulses reflected from the flat-bottom defect when the first and second bottom pulses are received, respectively.

Analysis of the data shown in Fig. 6 indicates the amplitudes ratio of the lunar pulse from a flat-bottomed defect with a diameter of $3 \mathrm{~mm}$ and noise is about 3/1. Accordingly, for a flat-bottomed defect with a diameter of $5 \mathrm{~mm}$, the amplitudes ratio of the lunar pulse and noise is about $7 / 1$, and from the reflector with a diameter of $8 \mathrm{~mm}$, about 20/1. That is, it can be concluded that the measurement control of defect models is sufficiently effective.

The amplitude ratio of the reflected impulse due to the defect to the noise amplitude not less than $20 \mathrm{~dB}$ (10 times) is set at a similar check detecting the model with a flat-bottomed defect with a diameter of $2 \mathrm{~mm}$, the model of EMAT under the above conditions, in the head of the reinforced rail, which material is substantially transparent for the shifting ultrasonic pulses.

It should be noted that between the first and second and between the second and third bottom pulses, the pulses are observed that are reflected from a defect of insignificant amplitude, which may be an additional sign of the presence of a reflector-defect. The additional use of such signals can significantly increase possibility of TO diagnostics.

Thus, it is possible to conclude that the use of pulsed sources of magnetic polarizing fields in EMAT with sufficient amplitude of the useful signal can provide measurement of the defects size in the amplitude magnitude of the received ultrasonic pulses, thus determining the quality of metal product.
Analysis of the developed type of EMA transducer from the metrological point of view showed that the results of its functioning are affected by a number of factors: random changes in the amplitude of the signals from the gap between the transducer and metal surface (exponential dependence); changes in inductance of the high frequency coil from distance to metal; stability of peak value of high-frequency power supply current; stability of peak value of magnetizing current; changes of surface condition of TO; presence or absence of scale on the surface of TO; duration of the probe pulse; "dead" zone of testing. This is a significant issue that requires further detailed studies to determine the impact of these factors on testing results.

\section{Conclusions}

Based on the analysis of the performed research and developments, the following conclusions can be formulated:

1. The method of ultrasonic electromagneticacoustic control of ferromagnetic products is developed, the essence of which is to excite ultrasonic pulses by forming in the surface layer of a ferromagnetic product two adjacent short-wave magnetized sections with opposite directed vectors of intensity lasting several periods of high frequency filling, the excitation of the electromagnetic field pulses is performed at a time equal to the time of transient processes with working value of the polarizing magnetic field induction, and the reception of ultrasonic pulses reflected from the product is performed in the time period $t_{\mathrm{pr}}$, which is determined by the expression

$$
T-t_{1}-t_{2}-t_{3}<t_{\mathrm{pr}}=t_{1}+t_{2}+t_{3}+2 H / C
$$

where $T-$ magnetization pulse duration; $t_{1}-$ time of transient processes to establish induction working value of the polarizing magnetic field; $t_{2}-$ time of batch pulse of electromagnetic field; $t_{3}$ - time of damping current oscillations in a flat high frequency inductance coil; $H$ - product thickness or the distance in the product volume that are subject to ultrasonic measurement control, $\mathrm{mm}$; $C$ - velocity of spreading shear ultrasonic waves in the product material is subject to control, $\mathrm{mm} / \mu \mathrm{s}$.

2. It is determined that the interference in the ferromagnetic core due to the Barkhausen effect and magnetostrictive transformation of electromagnetic energy into ultrasonic during excitation of ultrasonic pulses is virtually eliminated due to the production of the laminated magnetic field core, the material of electrically insulated core plates should have low magnetostrictive conversion factor and such plated should be oriented perpendicular to the conductors of the working areas of the flat high frequency coil, and filled with liquid having significant density, such as glycerin in the gaps between core plates. 
3. Based on the analysis results of the performed research, the requirements for the creation of EMAT with pulsed magnetization are formulated. The induction coils of the magnetic field source in the EMAT should be flat two-window and made of a whole plate of highly conductive and heat-conducting material and be three-turn. They should be used in conjunction with high frequency induction coils with two linear working sections. The windows of such coils of the magnetic field source should be located above the working areas of the high frequency induction coils. It is also necessary to use ferromagnetic laminated U-shape core.

4. It is determined that direct EMAT with flat magnet coils and ferromagnetic cores can provide ultrasonic non-contact measuring control of ferromag- netic products by shadowing, mirror-shadowing and echo methods with sensitivity close to traditional piezoelectrics. It is shown that the sensitivity of direct EMAT with pulsed magnetization provide detection of flat-bottom reflectors with a diameter of $2 \mathrm{~mm}$ and more at a sounding frequency of $40 \mathrm{~Hz}$, a frequency of linear polarized ultrasonic vibrations of $2.3 \mathrm{MHz}$, a peak batch pulse of high frequency currents of $120 \mathrm{~A}$, three-frequency current of $120 \mathrm{~A}$, the duration of the batch current in 6 periods of the filling frequency, magnetization pulse duration $200 \mu \mathrm{s}$, magnetization current $600 \mathrm{~A}$ and at the gap between the EMAT and the product $0.2 \mathrm{~mm}$. The amplitude of the echo momentum from the defect with respect to the noise amplitude reaches $20 \mathrm{~dB}$.

\title{
Електромагнітно-акустичні перетворювачі для ультразвукових вимірювань, контролю та діагностики феромагнітних металовиробів
}

\author{
Салам Буссі, Г.М. Сучков, Р.П. Мигущенко, О.Ю. Кропачек, \\ С. Ю. Плєснецов
}

Національний технічний університет “Харківський політехнічний інститут”, вул. Кирпичова, 2, 61002, Харків, Україна hpi.suchkov@gmail.com

\section{Анотація}

Ультразвукові методи дуже поширені при вимірюваннях, контролі та діагностиці. Ефективним різновидом ультразвукового методу є електромагнітно-акустичний метод, особливо при визначенні якості феромагнітних виробів. Основним фактором, який визначає ефективність використання електромагнітно-акустичних перетворювачів, $€$ величина індукції поляризуючого магнітного поля, яка визначається джерелом.

Дослідження, виконані в межах цієї роботи, спрямовані на вирішення проблем якісного вимірювального контролю металовиробів із феромагнітних матеріалів електромагнітно-акустичними перетворювачами.

Сформульовано вимоги до імпульсного джерела поляризуючого магнітного поля у складі електромагнітноакустичних перетворювачів, котушки індуктивності, осердя. 3 урахуванням вимог запропоновано конструктивні рішення для побудови електромагнітно-акустичних перетворювачів із плоскою двовіконною котушкою індуктивності та плоскою високочастотною котушкою індуктивності.

Виконано експериментальні дослідження, спрямовані на вдосконалення ультразвукових електромагнітно-акустичних перетворювачів з імпульсними джерелами магнітного поля. Показано можливість забезпечення чутливості нових перетворювачів при товщинометрії, вимірювальному контролі та діагностиці. Запропоновано технічні рішення, які зменшують вплив на ультразвукові імпульси, що приймаються, шумів Баркгаузена та когерентних завад від магнітострикційного перетворення електромагнітної енергії в ультразвукову.

Досліджено вплив форми осердя, кількості витків котушки, характеристик формування магнітного поля на завади в сигналі, що генерується та приймається електромагнітно-акустичним перетворювачем.

Показано ефективність використання електромагнітно-акустичних перетворювачів з імпульсним поляризуючим магнітним полем при вимірювальному контролі якості феромагнітних виробів, виготовлених прокаткою, штампуванням тощо.

Ключові слова: ультразвукові хвилі; електромагнітно-акустичний перетворювач; імпульсне намагнічування; матеріал для досліджень; феромагнітний; котушка індуктивності; вимірювання; контроль; діагностика; товщинометрія. 


\title{
Электромагнитно-акустические преобразователи для ультразвуковых измерений, контроля и диагностики ферромагнитных металлоизделий
}

\author{
Салам Бусси, Г.М. Сучков, Р.П. Мигущенко, О.Ю. Кропачек, \\ С.Ю. Плеснецов
}

Национальный технический университет “Харьковский политехнический институт”, ул. Кирпичева, 2, 61002, Харьков, Украина

hpi.suchkov@gmail.com

\section{Аннотация}

Ультразвуковые методы широко распространены при измерениях, контроле и диагностике. Эффективным видом ультразвукового метода является электромагнитно-акустический метод, особенно при определении качества ферромагнитных изделий.

Исследования, выполненные в рамках данной работы, направлены на решение проблем качественного измерительного контроля металлоизделий из ферромагнитных материалов электромагнитно-акустическими преобразователями.

Выполнены экспериментальные исследования, направленные на совершенствование ультразвуковых электромагнитно-акустических преобразователей с импульсными источниками магнитного поля. Показана возможность обеспечения чувствительности новых преобразователей при толщинометрии, измерительном контроле и диагностике. Предложены технические решения, которые уменьшают влияние на ультразвуковые импульсы принимаемых шумов Баркгаузена и когерентных помех от магнитострикционного преобразования электромагнитной энергии в ультразвуковую.

Исследовано влияние формы сердечника, количества витков катушки, характеристик формирования магнитного поля на помехи в сигнале, который генерируется и принимается электромагнитно-акустическим преобразователем.

Показана эффективность использования электромагнитно-акустических преобразователей с импульсным поляризующим магнитным полем при измерительном контроле качества ферромагнитных изделий, изготовленных прокаткой, штамповкой и т. п.

Ключевые слова: ультразвуковые волны; электромагнитно-акустический преобразователь; импульсное намагничивание; материал для исследований; ферромагнитный; катушка индуктивности; измерение; контроль; диагностика; толщинометрия.

\section{References}

1. Yermolov I. N., Lange Yu.V. Nerazrushayushhij kontrol: spravochnik. Ultrazvukovoj control [Non-destructive testing: guide. Ultrasonic testing]. Ed. by V. V. Klyuev. Vol. 3. Moscow, Mashinostroenie, 2004, 864 p. (in Russian).

2. Sudakova K. V., Kazjukevich I. L. O povyishenii effektivnosti kontrolya kachestva metallurgicheskoy produktsii [On improving the quality testing of metallurgical products]. NDT World, 2004, no. 3, pp. 8-10 (in Russian).

3. Semerenko A. V. Primenenie EMAP dlya kontrolya korrozii i erozii paronagrevateley kotelnyih ustanovok [Application of EMAT to test for corrosion and erosion of boiler heaters]. Territorija NDT, 2014, vol. 1, pp. 42-43 (in Russian).

4. Suchkov G.M. Rozvytok teorii i praktyky stvorennia pryladiv dlia elektromahnitno-akustychnoho kontroliu metalovyrobiv [Development of theory and practice of creating devices for electromagnetic-acoustic testing of metal products]. Author's abstract of Doctor's thesis. Kharkiv, NTU KhPI Publ., 2005. 37 p. (in Ukrainian).
5. Migushhenko R.P., Suchkov G.M., Radev H. K. et al. Elektromagnitno-akusticheskij preobrazovatel dlya ultrazvukovoj tolshinometrii ferromagnitnyh metalloizdelij bez udaleniya dielektricheskogo pokrytiya [Electromagnetic-acoustic transducer for ultrasonic thickness measurement of ferromagnetic metal products without removing the dielectric coating]. Tekhnichna Elektrodynamika, 2016, no. 2, pp. 78-82 (in Russian).

6. Mihajlov A. V., Gobov Ju.L., Smorodinskij Ja.G., Shherbinin S.V. Elektromagnitno-akusticheskij preobrazovatel s impulsnym podmagnichivaniem [Electromagnetic-acoustic transducer with pulse magnetization]. Defektoskopija, 2015, no. 8, pp. 14-23 (in Russian).

7. Suchkov G.M., Salam Bussi. Modeliuvannia poliaryzuiuchoho mahnitnoho polia elektromahnitno-akustychnoho peretvoriuvacha elektromahnitnoi enerhii v ultrazvukovu [Modeling of the polarizing magnetic field of an electromagnetic-acoustic transducer of electromagnetic energy into ultrasonic]. Proceedings of 19th International Scientific and Technical Conference "Problems of Informatics and Mo- 
deling” (Karolino-Bugaz, September 11-16, 2019). Kharkiv, NTU KhPI Publ., p. 79 (in Ukrainian).

8. Salam Bussi et al. Ultrazvukovyi peretvoriuvach dlia bezkontaktnoho kontroliu vyrobiv $\mathrm{z}$ feromahnitnykh materialiv [Ultrasonic transducer for contactless testing of ferromagnetic products]. Proceedings of the 1st International Scientific and Practical Internet Conference "Integration of Education, Science and Business in the Modern Environment: Summer Debates" (Dnipro, August 1-2, 2019), pp. 620-624 (in Ukrainian).
9. Salam Bussi et al. Potuzhnyi elektromahnitnoakustychnyi peretvoriuvach dlia ultrazvukovoho kontroliu metalovyrobiv [Powerful electromagnetic-acoustic transducer for ultrasonic testing of ferromagnetic products]. Non-Destructive Testing in Context of the Associated Membership of Ukraine in the European Union (NDT-UA 2019): Conference proceedings of the 3rd scientific conference with international participation (Kyiv, September 17-19, 2019), USNDT Publ., 2019, no. 3, pp. 50-51 (in Ukrainian). 